\title{
Fractionation of Rhizobium leguminosarum Cells into Outer Membrane, Cytoplasmic Membrane, Periplasmic, and Cytoplasmic Components
}

\author{
RUUD A. DE MAAGD* AND BEN LUGTENBERG \\ Botanical Laboratory, Department of Plant Molecular Biology, State University, 2311 VJ Leiden, The Netherlands
}

Received 5 November 1985/Accepted 4 February 1986

\begin{abstract}
Rhizobium leguminosarum cells were separated into four distinct fractions by using density gradient centrifugation for the separation of the outer and cytoplasmic membranes and lysozyme-EDTA treatment of whole cells for the isolation of the periplasmic and cytoplasmic fractions. These methods allowed the subcellular localization of $R$. leguminosarum proteins.
\end{abstract}

The gram-negative bacterium Rhizobium leguminosarum forms nitrogen-fixing nodules on plants of the pea crossinoculation group of the Leguminosae family (12). At least some of the genes involved in nodulation and fixation are located on large, so-called Sym(biosis) plasmids (4). To enable us to localize the products of these genes, we developed a procedure for the fractionation of $R$. leguminosarum cells.

Separation of cytoplasmic and outer membranes. The final procedure for membrane separation is a result of a number of modifications of the original methods of Osborn et al. (11) and Hancock and Nikaido (3). Logarithmic-phase cells of wild-type $R$. leguminosarum 248 (5) were obtained by overnight growth in $400 \mathrm{ml}$ of tryptone-yeast extract medium (1) to an $A_{620}$ of 0.5 to 0.6. All further parts of the procedure were carried out at 0 to $4^{\circ} \mathrm{C}$. After being harvested, the cells were suspended in $10 \mathrm{ml}$ of $50 \mathrm{mM}$ Tris, (pH 8.5)-20\% (wt/vol) sucrose-0.2 $\mathrm{mM}$ dithiotreitol supplemented with 0.2 mg of DNase I and RNase A per ml. The cells were broken by three passages through a French pressure cell at 25,000 $\mathrm{lb} / \mathrm{in}^{2}$. The broken-cell suspension was treated with $0.2 \mathrm{mg}$ of lysozyme per $\mathrm{ml}$ for $30 \mathrm{~min}$, subsequently diluted with 2 volumes of $50 \mathrm{mM}$ Tris ( $\mathrm{pH} \mathrm{8.5)}$, and centrifuged for $20 \mathrm{~min}$ at $900 \times g$ to remove unbroken cells. The supernatant fluid was supplemented with $\mathrm{KCl}$ to a final concentration of $0.2 \mathrm{M}$ and centrifuged for $2 \mathrm{~h}$ at $262,000 \times g$. The resulting pellet, containing the unseparated cell membranes, was carefully suspended in 0.5 to $1.0 \mathrm{ml}$ of $20 \%(\mathrm{wt} / \mathrm{wt}$ ) sucrose-5 mM EDTA-0.2 mM dithiothreitol ( $\mathrm{pH} 7.5)$ and layered on top of a discontinuous density gradient consisting of $0.5 \mathrm{ml}$ of $60 \%$, $0.5 \mathrm{ml}$ of $55 \%, 1.5 \mathrm{ml}$ of $50 \%, 3.0 \mathrm{ml}$ of $45 \%, 3.0 \mathrm{ml}$ of $40 \%$, $3.0 \mathrm{ml}$ of $35 \%, 3.0 \mathrm{ml}$ of $30 \%$, and $1.5 \mathrm{ml}$ of $25 \%$ (wt/wt) sucrose in $5 \mathrm{mM}$ EDTA (pH 7.5). The gradient was centrifuged for $17 \mathrm{~h}$ at 58,000 $\times \mathrm{g}$ in a Beckman SW27 rotor. This resulted in the banding pattern shown in Fig. 1A. The lower band was white and opaque, whereas the upper band was yellow and diffuse with, depending on the conditions of cell envelope preparation, various amounts of yellow particles (see below). A very minor, sharp, white band was often observed between the two major bands. Occasionally, an additional, very sharp band was observed between the major upper band and the top of the gradient. Fractions of $0.5 \mathrm{ml}$ were collected, and the relative protein content of the fractions was determined.

\footnotetext{
* Corresponding author.
}

As expected, the $A_{280}$ pattern of the gradient fractions (Fig. 1B) showed two major bands for which the peak fractions had buoyant densities of 1.243 and $1.147 \mathrm{~g} / \mathrm{cm}^{3}$. The distribution of the outer membrane marker 2-keto-3deoxyoctonate and the cytoplasmic membrane marker NADH oxidase (Fig. 1C) indicates that the separation of the two membranes was quite efficient. The lower band (fractions 1 to 9) had an average 2-keto-3-deoxyoctonate/protein ratio of $34 \mu \mathrm{g} / \mathrm{mg}$ and an average specific NADH oxidase activity of $17 \mu \mathrm{mol} / \mathrm{min}$ per mg. For the upper band (fractions 17 to 25 ) these values were $2 \mu \mathrm{g} / \mathrm{mg}$ and $74 \mu \mathrm{mol} / \mathrm{min}$ per $\mathrm{mg}$, respectively. Therefore, the lower and upper bands were identified as representing the outer and cytoplasmic membranes, respectively. The sharp intermediate band probably consists of unseparated cell envelopes. As judged from the total of the $A_{280}$ values of the bands as well as from their protein contents measured by the method of Markwell et al. (10), the two main membrane bands contained approximately equal amounts of protein. The protein patterns of the unevenly numbered fractions as analyzed by sodium dodecyl sulfate-polyacrylamide gel electrophoresis are shown in Fig. $1 D$.

It appeared that the presence of $0.2 \mathrm{M} \mathrm{KCl}$ during harvesting of the cell membranes improved the separation of the membranes in two ways. Firstly, the presence of $\mathrm{KCl}$ lead to the removal of contaminating soluble substances which tended to bind to the membranes, probably by ionic interactions. Also, the amount of a contaminant in the upper fractions of the gradient, probably nucleic acid because of a high $A_{260} / A_{280}$ ratio (1.8 in the absence of $\mathrm{KCl}$ ), was reduced. Secondly, the presence of $\mathrm{KCl}$ during membrane harvesting resulted in a much sharper upper band in the gradient which was probably due to the aggregation of the cytoplasmic membranes or to the removal of presumed nucleic acid contaminants from the cytoplasmic membranes. Lanes A and B of Fig. 2 show the polypeptide patterns of unfractionated cell envelopes harvested in the absence and presence of $\mathrm{KCl}$, respectively. The removal of lysozyme and of some other proteins in the low-molecular-weight range and a protein with a relative molecular weight of 60,000 as a result of the presence of $\mathrm{KCl}$ is clearly evident. Cell fractionation by lysozyme-EDTA treatment of cells at 0 to $4^{\circ} \mathrm{C}$ followed by osmotic lysis and density gradient centrifugation of membranes as described by Osborn et al. (11) sometimes yielded similar results. However, the problem was that the efficiency of lysis of $R$. leguminosarum after this treatment, 

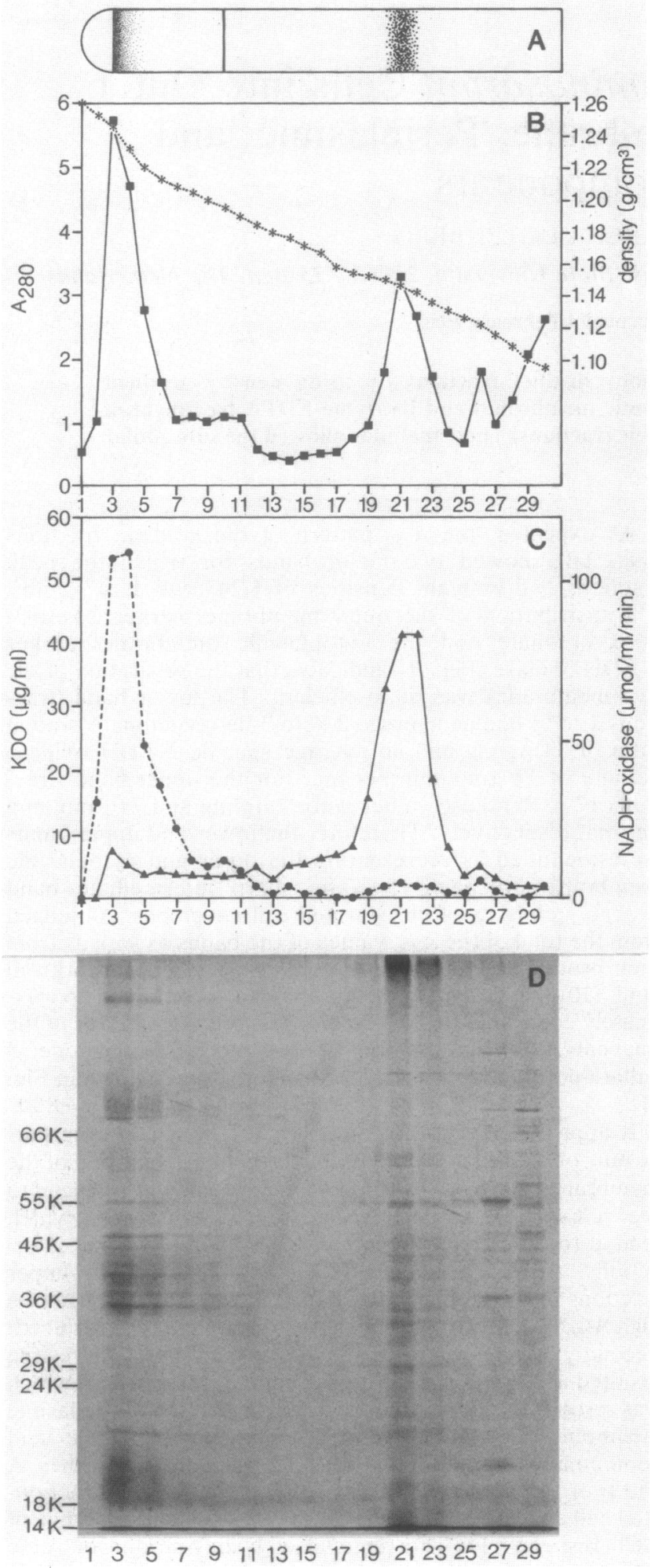

FIG. 1. Isopycnic sucrose density gradient centrifugation of cell membranes of $R$. leguminosarum 248 obtained after cell destruction with a French pressure cell, treatment with lysozyme, and harvesting in the presence of $0.2 \mathrm{M} \mathrm{KCl}$. (A) Schematic representation of bands observed after centrifugation. (B) $A_{280}$ values ( $\square$ ) and buoyant densities (*) of the gradient fractions. (C) 2-Keto-3-deoxyoctonate content $(O)$ and NADH oxidase activity $(\Delta)$ of the fractions. 2-Keto-3-deoxyoctonate content was estimated by using the

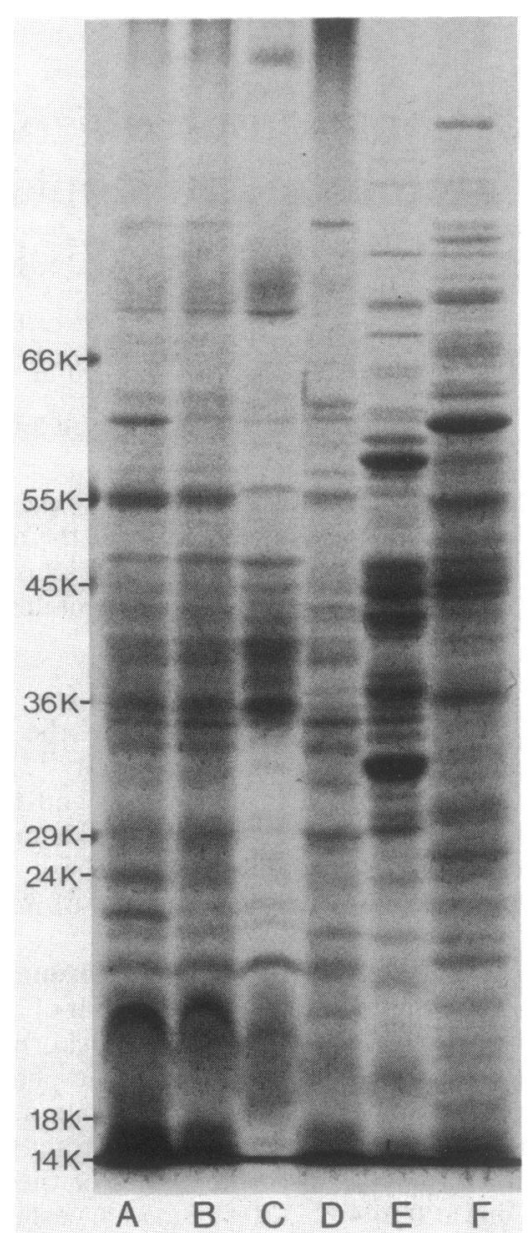

FIG. 2. Protein profiles of various $R$. leguminosarum cell fractions as analyzed by sodium dodecyl sulfate-polyacrylamide gel electrophoresis. Lanes: A, Unseparated cell envelopes, after lysozyme treatment, harvested in the absence of $\mathrm{KCl}$; $\mathrm{B}$, unseparated cell envelopes, after lysozyme treatment, harvested in the presence of $\mathrm{KCl} ; \mathrm{C}$, isolated outer membranes; $\mathrm{D}$, isolated cytoplasmic membranes; E, periplasmic fraction; F, cytoplasmic fraction. Procedures for the isolation of the various fractions are described in the text. The positions of molecular weight (in thousands) standard proteins are indicated at the left.

a prerequisite for efficient membrane separation, was not reproducibly high. Osmotic lability of the cells was insufficient, and extensive sonication was required for complete lysis, resulting in a relatively low yield of outer and cytoplasmic membrane fractions that coincided with a high yield of the intermediate band, which contained the markers of both membranes. Our standard procedure, based on cell destruction by a French pressure cell, lysozyme treatment of cell envelopes, and subsequent membrane separation by

thiobarbituric acid assay (6) after precipitation of fraction samples with $10 \%$ trichloroacetic acid. NADH oxidase was measured by the method of Osborn et al. (11). (D) Sodium dodecyl sulfatepolyacrylamide gel electrophoresis protein patterns of the unevenly numbered fractions. Electrophoresis and staining with fast green FCF were performed as described elsewhere (8). Fraction numbers are indicated below the panels. The positions of molecular weight (in thousands) standard proteins are indicated at the left of panel D. 
density gradient centrifugation also yielded good results with another $R$. leguminosarum strain, RBL1, and with $R$. trifolii RBL5020.

Isolation of periplasmic and cytoplasmic fractions. For the isolation and identification of the periplasmic and cytoplasmic fractions, we used strain RBL1-AP4, a mutant of wildtype strain RBL1 which is constitutive for alkaline phosphatase, as well as strain 248 . We modified the method of Glenn and Dilworth (2) as follows. The cells were grown as described above in $40 \mathrm{ml}$ of tryptone-yeast extract medium and harvested by centrifugation at room temperature. The pellet was suspended in $5 \mathrm{ml}$ of $50 \mathrm{mM}$ Tris (pH 8.0)-20\% (wt/vol) sucrose-2 mM EDTA-0.2 mg of lysozyme per ml and incubated at room temperature for $30 \mathrm{~min}$. The cells were pelleted by centrifugation at $4^{\circ} \mathrm{C}$. Part of the supernatant fluid was kept apart for measuring the activities of malate dehydrogenase and alkaline phosphatase, markers for the cytoplasmic and periplasmic fractions, respectively. Periplasmic proteins were precipitated from the supernatant by the addition of 5\% trichloroacetic acid. The precipitate was collected by centrifugation, washed three times with diethyl ether, and dissolved in sample buffer for sodium dodecyl sulfate-polyacrylamide gel electrophoresis.

To isolate the cytoplasmic proteins, we lysed the remaining cells by suspension in $50 \mathrm{mM}$ Tris $(\mathrm{pH} \mathrm{8.0)}$, followed by brief sonication. A small fraction was kept apart for measuring enzyme activities. Subsequently, unbroken cells were pelleted, the supernatant fluid, containing cytoplasmic proteins and cell envelopes, was further diluted, and $\mathrm{KCl}$ was added to a final concentration of $0.2 \mathrm{M}$. Cell envelopes were removed by centrifugation at $262,000 \times g$ for $2 \mathrm{~h}$ at $4^{\circ} \mathrm{C}$. Cytoplasmic proteins were precipitated from the supernatant with $5 \%$ trichloroacetic acid and treated further as described for the periplasmic proteins.

Alkaline phosphatase was assayed by measuring the rate of increase of the $\boldsymbol{A}_{420}$ in a 1-ml test solution containing 0.1 M Tris hydrochloride ( $\mathrm{pH} 8.6$ ), $0.4 \mathrm{M} \mathrm{MgCl}, 0.4 \mathrm{mg}$ of f-nitrophenol phosphate per $\mathrm{ml}$, and $100 \mu \mathrm{l}$ of enzyme solution (9). Malate dehydrogenase was assayed by measuring the rate of decrease of the $A_{340}$ during the conversion of oxaloacetate to malate with $\mathrm{NADH}$ as the cofactor. Test solutions of $1.1 \mathrm{ml}$ contained $50 \mathrm{mM} \mathrm{N}$-2-hydroxyethylpiperazine- $N^{\prime}-2^{\prime}$-ethanesulfonic acid (HEPES), (pH 7.2), 0.3 $\mathrm{mM} \mathrm{NADH}$, and $100 \mu$ l of enzyme solution. Before starting the reaction by the addition of $25 \mu \mathrm{l}$ of $10 \mathrm{mM}$ oxaloacetate solution, we measured the endogeneous NADH oxidase activity (7).

Although lysozyme-EDTA treatment released periplasmic proteins efficiently, microscopic examination showed that only a small percentage of spheric cells was formed. However, the cells appeared to be sensitive to lysis by osmotic shock.

Treatment of cells of strain RBL1-AP4, grown in tryptoneyeast extract medium, with lysozyme-EDTA released an average of $88 \%( \pm 2 \%)$ of the total alkaline phosphatase activity into the medium, whereas only $3 \%( \pm 1 \%)$ and $4 \%$ $( \pm 2 \%)$ of the total activity of the cytoplasmic enzyme malate dehydrogenase was released from cells of strains 248 and
RBL1-AP4, respectively. These results indicate that the method used is efficient in releasing periplasmic proteins, whereas it leaves the cytoplasmic membrane intact. The cytoplasmic fraction could be obtained after lysis of the cells by osmotic shock, followed by sonication, with subsequent removal of the cell envelopes by centrifugation. The latter fraction appeared to contain 0 to $2 \%$ of the total recovered malate dehydrogenase activity. A comparison of the proteins of the various cell fractions by sodium dodecyl sulfatepolyacrylamide gel electrophoresis (Fig. 2, lanes C, D, E, and $F$ ) confirms that the four cell fractions have unique protein patterns.

In conclusion, the two methods described here enable us to localize any given protein in one of the four compartments of the cell, provided that it is present in detectable amounts. Membrane separation will also allow a study of the role of cell surface proteins in nodulation.

We thank Ton A. N. van Brussel for R. leguminosarum RBL1AP4 and for advice on alkaline phosphatase assays and both him and Carel Wijffelman for stimulating discussions.

\section{LITERATURE CITED}

1. Beringer, J. E. 1974. $\mathrm{R}$ factor transfer in Rhizobium leguminosarum. J. Gen. Microbiol. 84:188-189.

2. Glenn, A. R., and M. J. Dilworth. 1979. An examination of Rhizobium leguminosarum for the production of extracellular and periplasmic proteins. J. Gen. Microbiol. 112:405-409.

3. Hancock, R. E. W., and H. Nikaido. 1978. Outer membranes of gram-negative bacteria. XIX. Isolation from Pseudomonas aeruginosa $\mathrm{PAO} 1$ and use in reconstitution and definition of the permeability barrier. J. Bacteriol. 136:381-390.

4. Hooykaas, P. J. J., A. A. N. van Brussel, H. den Dulk-Ras, G. M. S. van Slogteren, and R. A. Schilperoort. 1981. Sym plasmid of Rhizobium trifolii expressed in different rhizobial species and in Agrobacterium tumefaciens. Nature (London) 291:351-353.

5. Josey, D. P., J. L. Beynon, A. W. B. Johnston, and J. E. Beringer. 1979. Strain identification in Rhizobium using intrinsic antibiotic resistance. J. Appl. Bacteriol. 46:343-350.

6. Keleti, G., and W. H. Lederer (ed.). 1974. Handbook of micromethods for the biological sciences, p. 74-75. Van Nostrand Reinhold Co., New York.

7. Kitto, G. B. 1969. Intra- and extramitochondrial malate dehydrogeneases from chicken and tuna heart. Methods Enzymol. 13:106-116.

8. Lugtenberg, B., J. Meyers, R. Peters, P. van der Hoek, and L. van Alphen. 1975. Electrophoretic resolution of the major outer membrane protein of Escherichia coli $\mathrm{K} 12$ into four bands. FEBS Lett. 58:254-258.

9. Malamy, M. H., and B. L. Horecker. 1964. Release of alkaline phosphatase from cells of Escherichia coli upon lysozyme spheroplast formation. Biochemistry 3:1889-1893.

10. Markwell, M. A. K., S. M. Haas, L. L. Bieber, and N. E. Tolbert. 1978. A modification of the Lowry procedure to simplify protein determination in membranes and lipoprotein samples. Anal. Biochem. 87:206-210.

11. Osborn, M. J., J. E. Gander, E. Parisi, and J. Carson. 1972. Mechanism of assembly of the outer membrane of Salmonella typhimurium. J. Biol. Chem. 247:3962-3972.

12. Vincent, J. M. 1974. Root-nodule symbiosis with Rhizobium, p. 265-341. In A. Quispel (ed.), Biology of nitrogen fixation. North-Holland Publishing Co., Amsterdam. 